\title{
ANALYSIS OF THE IMPACT OF THE AGROSECTOR'S SHARE ON DIFFERENCES IN THE PERFORMANCE OF REGIONS AT NUTS-III LEVEL: A CASE STUDY OF THE SLOVAK REPUBLIC
}

\author{
Monika Daňová ${ }^{142}$ \\ Ivana Kravčáková Vozárová ${ }^{143}$ \\ Roman Vavrek ${ }^{144}$
}

https://doi.org/10.31410/itema.2018.337

\begin{abstract}
There are differences between the territorial units of each economy, which can be easily quantified using the economic performance indicators of the region. The causes of regional disparities are the natural, geographical, environmental and demographic conditions of localization of economic activities. These specified types of conditions represent assumptions or limitations in the formation of the sectoral structure of economic activities in the territory. Opinions of theorists and empirical findings confirm that each of the sectors has a different ability to contribute to the formation of national product, gross fixed capital as well as added value. Due to the different economic effects of the represented sectors, there may be a gradual increase in differences in economic performance of territorial units or even loss of ability of independent development of the region. Accordingly, it can be stated the existence of regional disparities between the territorial units of the Slovak Republic at the regional level. Differences are identified in a different representation of sectors on the economic structure of the territory, in the value of GDP creation as well as the formation of fixed capital of individual regions. Agrosector is considered as the sector with the least contribution to the creation of a national product. Therefore, in the manuscript we analyze the existence and the strength of the relationship between the share of the agricultural sector in the structure of the economy and the indicators of the economic performance of the region as well as the existence or absence of a trend of increasing interregional differences. In order to identify the preservation of the development capacities of territorial units, we analyzed also the differences in the ability of regions with different range of agrosectors to form development capital.
\end{abstract}

Keywords: agrosector, economic performance, differences, regions, Slovak Republic

\section{INTRODUCTION}

7 he economic development of countries is reflected not only in the growth rates of gross domestic product per capita, but also in the structural transformation of the economy. These transformations represent changes in the nature of the economy and in the role of particular activities of the economy. The changes take place, inter alia, in the three-sector structure of the economy. Theoretical basis for the analysis is comprised in the three-sector theory of economy put forward by Fisher, Clark and Fourastie [1] - [3], who have identified the

\footnotetext{
142 Department of Economics and Economy, Faculty of Management, University of Prešov in Prešov, Konštantínova 16, Prešov, Slovakia

143 Department of Economics and Economy, Faculty of Management, University of Prešov in Prešov, Konštantínova 16, Prešov, Slovakia

${ }^{144}$ Department of Informatics, Faculty of Economics, Technical University of Liberec, Voroněžská 1329/13, Liberec, Czech Republic
} 
agricultural sector, industrial sector, and the service sector in various areas of economic activity [4]. Transformation of agriculture from the dominant sector in relatively poor countries to a very small sector in the richest countries is a major feature of economic development. After 1960, it can be observed downward trend in the share of agriculture sector in the total GDP in most developed economies in the world, including Western Europe. In Eastern European countries, this trend is gaining after 1989.

\section{THEORETICAL BACKGROUND}

The primary causes of historical development of the structure of national economic activities consist in changes in demand for the production of individual sectors, most often in growing demand for industrial production and growing demands for the provision of services of various kinds.

The economic changes taking place in Central and Eastern European countries are rooted in market-based mechanisms that have created new avenues of social and economic development in the region and have altered well-established economic systems. Changes of this type have prompted adjustments in social and economic structures, which have responded to changing economic conditions in the global marketplace [5].

This development has its consequences and given the variety of causes and the severity of these consequences, this issue is given a great deal of attention both in economic practice and at academic level. There are a number of studies that confirm the gradual reduction of the primary sector on the basis of empirical observations of the long-term development of the structure of the economic system. There are several indicators to measure the performance of agricultural production. The role of agriculture in a national economy is best characterized by the share of agriculture in GDP, which is shrinking all over the world [6].

Older and also more recent published studies are looking for the causes of a reduction in the share of the agricultural sector mainly in market and economic factors. The most causes are of a political nature - pricing policy in the agricultural and industrial sectors has a significant impact on the relative prices of these goods, and in the least developed countries a negative impact on agricultural production [7]. Some authors argue that the size of the rural population positively determined the percentage contribution of agriculture to GDP. Thus for regions with larger rural populations the percentage contribution of agriculture to GDP was higher suggesting that the greater supply of rural labour was responsible for relatively higher agricultural production [8].

For other authors, the availability of resources is a factor of the economic growth of the sectors [9] - [11]. The primary sector is linked to the availability of natural resources, the secondary sector with the availability of technical factors, and the development of the tertiary sector is linked to the human capabilities. These factors, according to the authors, determine growth of the sector, localization of the sectors into specific areas and consequently limit the economic growth of these areas. The regions with a high proportion of the agricultural sector have traditionally lower GDP and lower living standards, measured by income per capita [12]. The result is the deterioration of the economic situation of the rural population, the emergence of regional disparities in the social and pension situation of the population, then the gradual outflow of inhabitants from these areas into larger agglomerations, and thus the reduction of the autonomous development capacity of the area. 


\section{METHODOLOGY}

The aim of the submitted contribution is to identify the positive impact of the agrosector on preservation of developmental capacities of territorial units. The solution is based on the quantification of the relationship between the share of the agricultural sector in the structure of the economy and the economic performance indicators of the region as well as the existence or absence of a tendency to increase interregional disparities.

To fulfill this goal, we have identified four indicators that were the subject of further analysis. The aim of the set of indicators is to capture the linkage between the development of agriculture and the overall development of the region. The monitored indicators are:

- GDP per $\mathrm{m}^{2}$ (Gross Domestic Product),

- total GVA per $\mathrm{m}^{2}$ (Total Gross Value Added)

- agriculture GVA per $\mathrm{m}^{2}$ (Agriculture Gross Value Added),

- agricultural production per $\mathrm{m}^{2}$.

The relationship between the above indicators is monitored:

a) using a simple regression model whose veracity is verified by the coefficient of determination:

$$
R^{2}=\frac{\sum_{i=1}^{n}\left(y_{i}-\hat{y}_{i}\right)^{2}}{\sum_{i=1}^{n}\left(y_{i}-\bar{y}_{i}\right)^{2}}
$$

where: $y_{i}$ - measured value of dependent variable

$\hat{y}_{i}$ - estimated value of dependent variable

$\bar{y}_{i}$ - average value of dependent variable

b) by using a sequence correlation analysis (due to the failure to prove the normality of the input data), namely the Kendall coefficient:

$$
r_{K}=\frac{n_{c}-n_{d}}{n(n-1) / 2}
$$

where: $n$ - number of observations of pair of variables

$n_{c}$ - number of discordant pairs

$n_{d}$ - number of concordant pairs

Due to higher objectivity, the interpretation of the results obtained during the monitored period $2000-2016$ is supplemented by year-to-year indices and variation coefficient. All analyzes are processed in MS Excel, Statgraphics and Statistics.

\section{RESULTS AND DISCUSSION}

The first step of the analysis is the identification of trends in the development of agricultural production in individual regions of Slovakia. The development of this indicator (EUR per $\mathrm{m} 2$ of agricultural land) over the reference period is captured in Figure 1. 
Figure 1: Trend of agricultural production development in the monitored period

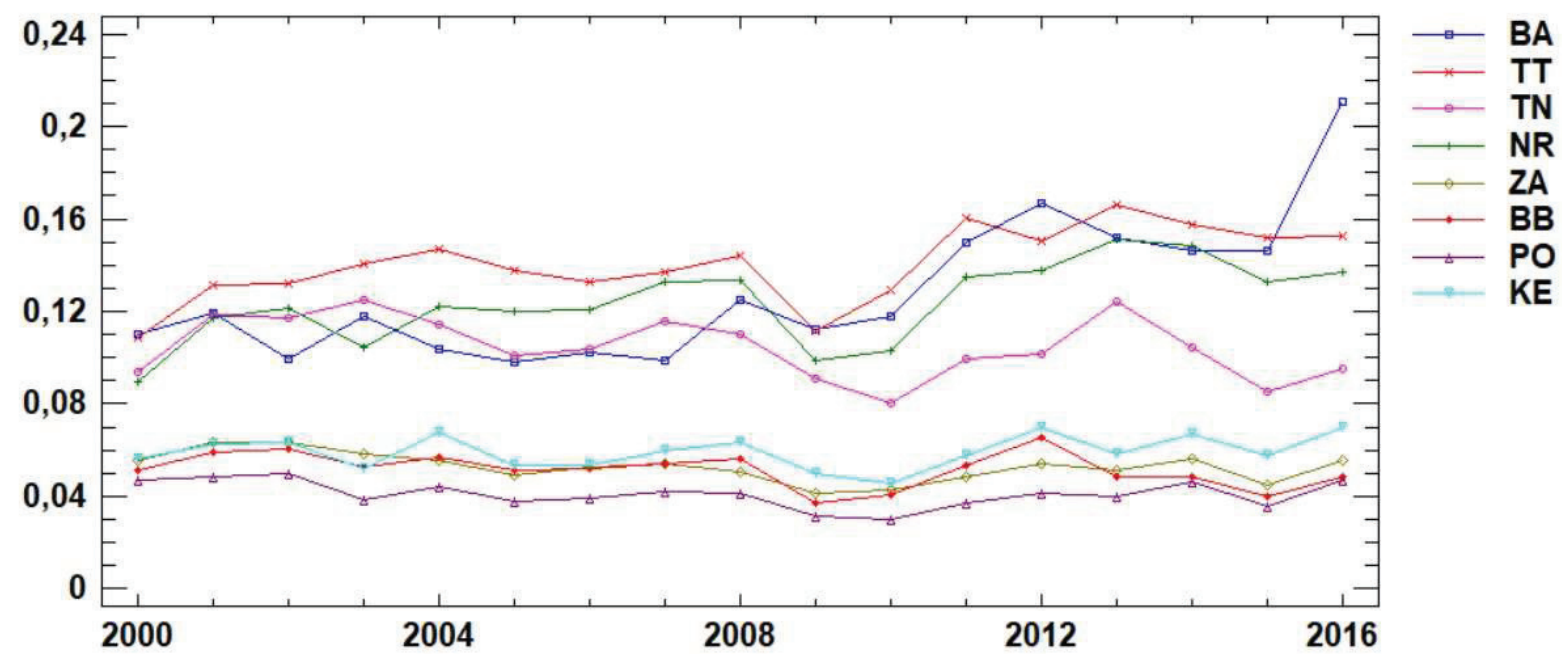

where: BA - Region of Bratislava, TT - Region of Trnava, TR - Region of Trenčín, NR - Region of Nitra, ZA - Region of Žilina, BB - Region of Banská Bystrica, PO - Region of Prešov, KE - Region of Košice

As we can see in Figure 1, there are differences in absolute values between regions, that prove the dominance of the regions located in Western Slovakia. Differences can be also observed in the overall development, year-on-year changes and overall variability over the period 2000-2016.

Table 1: Comparison of the development of agricultural production in individual regions of the SR

\begin{tabular}{|c|c|c|c|c|}
\hline \multirow{2}{*}{ Region } & \multicolumn{2}{|c|}{ Model without intercept } & \multirow{2}{*}{$\begin{array}{l}\text { avg yearly } \\
\text { index }\end{array}$} & \multirow{2}{*}{$\mathrm{CoV}$} \\
\hline & R-squared & Slope & & \\
\hline Region of Bratislava & 0,9505 & 0,00636764 & 1,053008 & 0,237104 \\
\hline Region of Trnava & 0,9887 & 0,00700590 & 1,027183 & 0,111831 \\
\hline Region of Trenčín & 0,9851 & 0,000052160 & 1,010872 & 0,126073 \\
\hline Region of Nitra & 0,9826 & 0,000061685 & 1,036235 & 0,139003 \\
\hline Region of Žilina & 0,9870 & 0,000026281 & 1,006946 & 0,116989 \\
\hline $\begin{array}{l}\text { Region of Banská } \\
\text { Bystrica }\end{array}$ & 0,9808 & 0,000025619 & 1,011749 & 0,143245 \\
\hline Region of Prešov & 0,9817 & 0,000020441 & 1,012598 & 0,139965 \\
\hline Region of Košice & 0,9869 & 0,000029497 & 1,027932 & 0,119195 \\
\hline
\end{tabular}

Based on the above results, there is a positive trend in agricultural production in all regions, which is minimal. Average year-on-year changes over the entire observed period range from 0.69 to $5.30 \%$. The variability expressed by the coefficient of variation in any region was not lower than $11 \%$, i.e. negative and positive fluctuations are de facto compensated for each other. The difference region is BSK with significantly different variability and small average annual change. The linear relationship of agricultural production (EUR per $\mathrm{m} 2$ of agricultural land) with the other monitored indicators is captured in Table 2. 
Table 2: Correlation of agricultural production with selected indicators

\begin{tabular}{|l|l|l|l|}
\hline \multicolumn{1}{|c|}{ Region } & GDP & GVA - all & GVA - agr. \\
\hline Region of Bratislava & $0,49^{*}$ & $0,49^{*}$ & $0,46^{*}$ \\
\hline Region of Trnava & $0,54^{*}$ & $0,54^{*}$ & $0,60^{*}$ \\
\hline Region of Trenčín & $-0,28$ & $-0,28$ & $-0,17$ \\
\hline Region of Nitra & $0,54^{*}$ & $0,54^{*}$ & $0,57^{*}$ \\
\hline Region of Žilina & $-0,29$ & $-0,29$ & $-0,09$ \\
\hline Region of Banská Bystrica & $-0,28$ & $-0,28$ & $-0,17$ \\
\hline Region of Prešov & $-0,20$ & $-0,20$ & $-0,12$ \\
\hline Region of Košice $* 0,16$ & 0,16 & 0,24 \\
\hline
\end{tabular}

Based on the relationships captured above, the regions can be divided into two groups. The first group are the regions where agricultural production was significantly correlated with other indicators. This group included 3 regions in the west of the country (BA, TN, NR). In this group, therefore, there is no change in the relative differences between the output in agriculture and the total output in the region in the period under review. In the other five counties, this indicator does not linearly correlate with other indicators, while the observed differences are noted in Table 2 .

Table 3: Comparison of development of indicators in selected regions of the Slovak Republic

\begin{tabular}{|c|c|c|c|c|c|}
\hline \multirow{2}{*}{ Region } & \multirow{2}{*}{ Indicator } & \multicolumn{2}{|c|}{ Model without intercept } & \multirow{2}{*}{$\begin{array}{l}\text { avg yearly } \\
\text { index }\end{array}$} & \multirow{2}{*}{ CoV } \\
\hline & & R-squared & slope & & \\
\hline \multirow{4}{*}{ Region of Trenčín } & GDP & 0,8900 & 0,001452820 & 1,079246 & 0,365100 \\
\hline & GVA - all. & 0,8881 & 0,001131372 & 1,080221 & 0,368598 \\
\hline & GVA - agr. & 0,8800 & 0,000042416 & 1,096240 & 0,379251 \\
\hline & AP & 0,9851 & 0,000052160 & 1,010872 & 0,126073 \\
\hline \multirow{4}{*}{ Region of Žilina } & GDP & 0,8640 & 0,00121432 & 1,091979 & 0,411607 \\
\hline & GVA - all. & 0,8622 & 0,00109827 & 1,092870 & 0,414893 \\
\hline & GVA - agr. & 0,9368 & 0,000028607 & 1,073643 & 0,269952 \\
\hline & $\mathrm{AP}$ & 0,9870 & 0,000026281 & 1,006946 & 0,116989 \\
\hline \multirow{4}{*}{$\begin{array}{c}\text { Region of Banská } \\
\text { Bystrica }\end{array}$} & GDP & 0,8987 & 0,000593327 & 1,078392 & 0,348864 \\
\hline & GVA - all. & 0,9470 & 0,00536498 & 1,079430 & 0,352365 \\
\hline & GVA - agr. & 0,8516 & 0,000042673 & 1,121818 & 0,432956 \\
\hline & AP & 0,9808 & 0,000025618 & 1,011749 & 0,143245 \\
\hline \multirow{4}{*}{ Region of Prešov } & GDP & 0,8687 & 0,000627537 & 1,090408 & 0,403577 \\
\hline & GVA - all. & 0,8668 & 0,000567523 & 1,091299 & 0,406925 \\
\hline & GVA - agr. & 0,8991 & 0,000030586 & 1,086341 & 0,347848 \\
\hline & AP & 0,9817 & 0,000020441 & 1,012598 & 0,139965 \\
\hline \multirow{4}{*}{ Region of Košice } & GDP & 0,8924 & 0,000955296 & 1,080483 & 0,360696 \\
\hline & GVA - all. & 0,8906 & 0,000863796 & 1,081429 & 0,364050 \\
\hline & GVA - agr. & 0,8983 & 0,000030837 & 1,088727 & 0,349356 \\
\hline & AP & 0,9869 & 0,000029497 & 1,027932 & 0,119195 \\
\hline
\end{tabular}

Based on the above calculations, we note especially the differences in growth rate, expressed as the regressed value as well as the average annual index (GDP, GVA - all). When comparing agricultural production with the last indicator (GVA - agr.), the difference is mainly their variability, respectively constancy of indicators $(\mathrm{CoV})$. 
Figure 2: Comparison of regression functions in PSK

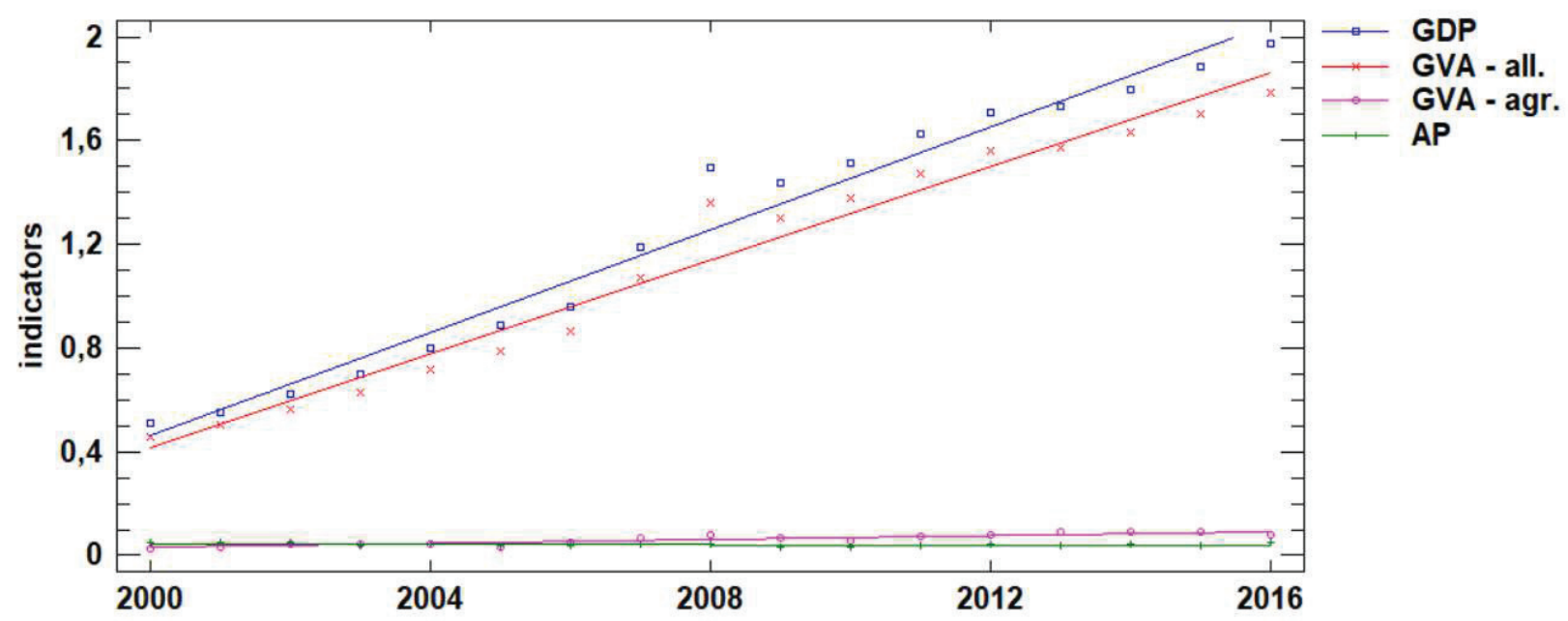

Over the years, the differences between agricultural production and the other two monitored indicators have increased significantly. The reason for this is the stagnation of agricultural production, as well as the constant growth of these indicators - GDP and total GVA. When comparing agricultural production with GVA in this sector, it is possible to follow a similar trend but with different variability, i.e. GVA in this sector is significantly more heterogeneous.

\section{CONCLUSION}

There are differences between the territorial units of each country. These can be identified both in economic and social terms. According to the empirical findings and opinions of academics, the reason for the emergence of regional disparities is the existence of prerequisites for the localization of certain types of economic activities into the territory. It regards the presence or absence of primary (natural) and secondary (personnel and capital resources) assumptions. Their occurrence results in a different structure in the region of localized sectors.

The analyses carried out on the economic performance data set of the self-governing regions of Slovak Republic confirm the existence of regional disparities. On the basis of a comparison of territorial performance through GDP per capita, the self-governing regions of the Slovak Republic can be divided into two groups. The dominant regions are the self-governing regions located in the West Slovakia. Economically less efficient are territorial units located in worse geographical conditions, with a higher share of rural area and lower density of economic activities (TT, ZA, BB, PO, KE).

The reason for the increase of regional disparities may be the larger share of sectors that are considered as less efficient and less able to form development capital. In view of the above criteria, the agriculture is generally considered to be such a sector. On the monitored sample of self-governing regions, we identified the difference in the ability of the sector to form fixed capital. As in the previous case, the magnitude of these differences can be assessed in two groups of self-governing regions - a smaller lag compared to the region's average was confirmed in a group of more economically developed regions (BA, TN, NR) than in economically less developed regions.

The third level of examination consisted in analyzing development trends. Long-term lower formation of fixed capital and value added of the agricultural sector may be the cause of the increase of regional disparities. According to our findings, with the years, the differences 
between agricultural output and the other two monitored indicators have significantly increased. The reason is the stagnation of agricultural production and the constant growth of GDP and total GVA. When comparing agricultural production with GVA in this sector, it is possible to follow a similar trend but with different variability, i.e. GVA in this sector is significantly more heterogeneous.

\section{ACKNOWLEDGEMENT}

This paper is supported by the Cultural and Educational Grant Agency of the Ministry of Education, Science, Research and Sport of the Slovak Republic under Grant (KEGA 035PU4/2016 - „Microeconomics for managers - innovation of the structure, content and methods of teaching the subject"), and by the Scientific Grant Agency of the Ministry of Education, Science, Research and Sport of the Slovak Republic and the Slovak Academy of Sciences under Grant (VEGA 1/0139/16 - „The analysis of the determinants and factors affecting the efficiency and competitiveness of entities working the soil in Slovakia" and Grant (VEGA 1/0578/18 „A modification of the methodologies for the sustainable development assessment"). This work was also supported by the OP VVV under Grant No. CZ.02.2.69/0.0/0.0/16_027/0008493.

\section{REFERENCES}

[1] Fisher A. (1939) Production, primary, secondary and tertiary. Economic Record 15(1), pp. 24-38.

[2] Clark C. (1940) The conditions of economic progress, Macmillan, London.

[3] Fourastié J. (1949). Le grand espoir du XXe siecle. Progress technique, progress economique, progress social, Presses Universitaires de France, Paris.

[4] Kwiatkowski E., Krzetowska A. (2015) The three-sector employment structure and economic development: comparative analysis of Poland and Ukraine-in the years 1990-2013. Economy and Forecasting, Valeriy Heyets, 3, pp. 145-154.

[5] Rachwal, T. (2011) Industrial restructuring in Poland and other European Union states in the era of economic globalization. Procedia Social and Behavioral Sciences 19 (2011), pp. 1-10.

[6] Csaki, C., Jambor, A. (2013) The impacts of EU accession on the agriculture of the Visegrad countries. Society and Economy 35(3), pp. 343-364.

[7] Kreuger, A., Schifr, M., Valdes, A. (1988) Agricultural incentives in developing countries: measuring the effect of sectoral and economy wide policies. World Bank Economic Review 2(3), pp. 255-71.

[8] Sormeaux, A., Pemberton, C. (2011) Factors Influencing Agriculture's Contribution to GDP: Latin America and the Caribbean. Caribbean Agro-Economic Society (29th West Indies Agricultural Economics Conference, July 17-21, 2011), Saint Vincent, West Indies.

[9] Wolfe, M. (1995) The Concept of Economic Sectors. Quarterly Journal of Economics, 69(3), pp. 402-420.

[10]Ferencz, V. Majerník M., Chodasová, Z., Adamišin, P., Štofková, Z., Sančiová, G., Danishjoo, E. (2017) Sustainable socio-economic development, A\&A Digitalprint, Düsseldorf.

[11]Huttmanová, E. (2017) The possibilities of sustainable development evaluation in the European union area. European journal of sustainable development 6(3), pp 75-80.

[12]Lacina, L., Mináŕik, B. (2002) Impact of agricultural sector on the economic situation of NUTS III regions in the Czech Republic. Agricultural Economics - Czech, 48(10), pp. 444-448. 